\title{
EFFECT OF VARIOUS LEVELS OF BIOCHAR INCORPORATION ON SOYBEAN YIELDS, PHYSICAL QUALITY AND NITRIFYING BACTERIA OF BLACK SOIL IN NORTHEAST CHINA
}

\author{
JIN, L. ${ }^{1,2 \#}-$ WEI, D. ${ }^{*}{ }^{*}-$ YIN, D. ${ }^{3 \#}-$ ZHOU, B. ${ }^{2}-$ LI, Y. ${ }^{2}-$ WANG, W. ${ }^{2}-$ ZHANG, J. ${ }^{2}-$ YU, S. ${ }^{4}-$ \\ JIANG, Y. ${ }^{5}-\mathrm{LI}, \mathrm{Y}^{6}{ }^{6}-\mathrm{CAI}, \mathrm{S}^{2,7}$
}

${ }^{I}$ Plant Nutriention and Resources Institute, Beijing Academy of Agriculture and Forestry Sciences, Beijing 100097, China

${ }^{2}$ Soil Fertilizer and Environment Resource Institute, Heilongjiang Academy of Agriculture and Science, The Key Laboratory of Soil Environment and Plant Nutrition of Heilongjiang Province, Harbin 150086, China

${ }^{3}$ College of Agricultural Science and Technology, Heilongjiang Bayi Agricultural University, Daqing, Heilongjiang 163319, China

${ }^{4}$ Institute of Crop Cultivation and Tillage, Heilongjiang Academy of Agricultural Sciences, Harbin 150027, China

${ }^{5}$ Heihe Branch of Heilongjiang Academy of Agriculture and Sciences, Heihe 164300, China

${ }^{6}$ College of Resources and Environment, Northeast Agricultural University, Harbin 150030, China

${ }^{7}$ College of Land and Environment, Shenyang Agricultural University, Shenyang 110866, China

${ }^{\#}$ These authors contributed equally to this research and should be considered as co-first authors

*Corresponding author

e-mail: jinliang19762003@aliyun.com

(Received 12 $2^{\text {th }}$ Jul 2019; accepted 30 $0^{\text {th }}$ Sep 2019)

\begin{abstract}
Maize-straw biochar (BC) was applied in a black soil area in Northeast China for investigating its effects on crop yield, soil physical properties and nitrifying bacteria. In this study, $\mathrm{BC}$ forms $\mathrm{BC}$, $\mathrm{BC} 2$ and $\mathrm{BC} 3$ were incorporated at levels of $15.75,31.50$ and $47.25 \mathrm{t} \mathrm{ha}^{-1}$, respectively, from 2013 to 2014. The control soil was treated with chemical fertilizer (NPK). The results showed that yields of soybean were significantly improved overall due to BC applications, compared with the control. Meanwhile, average soil compaction values of $0-20 \mathrm{~cm}$ deep soil were decreased from $17.9 \%$ to $47.4 \%$. Biochar supplementation decreased the soil wilting coefficients, but increased saturated water content. The available soil water content increased from 0.211 to $0.329 \mathrm{~cm}^{3} \mathrm{~cm}^{-3}\left(\mathrm{R}^{2}=0.97\right)$, whereas the bulk density decreased from 1.42 to $1.40 \mathrm{~g} \mathrm{~cm}^{-3}\left(\mathrm{R}^{2}=0.97\right)$ in response to $\mathrm{BC}$ supplementation. Unexpectedly, soybean yields began to decline at 31.50 and $47.25 \mathrm{t} \mathrm{ha}^{-1}$ of $\mathrm{BC}$ application. as well as soil aggregate stability, available water content, and capillary pores, mainly. Moreover, the BC supplementation significantly affected soil ammonia-oxidizing archaea (AOA) abundance. These results demonstrate that $\mathrm{BC}$ has positive potential for enhancing crop and soil properties performances in black soil at the level of $15.75 \mathrm{t} \mathrm{ha}^{-1}$ under continuous soybean system.
\end{abstract}

Keywords: maize-derived biochar, application levels, physical properties, field experiment, black soil 


\section{Introduction}

Given the growth rates since 1960, the global population is expected to reach 9.7 billion by 2050 (Gonzalo et al., 2016). The consequences of human population growth have great impacts on the environment, and also on social and economic development. China accounts for approximately $22 \%$ of the world's population which is expected to increase to 14.53 billion by 2030 (Yin and Guo, 2015). Consequently, the additional food required to feed future generations would challenge the production capacity of arable land in the years to come (Golley and Zheng, 2015). The agricultural sustenance of a growing population in the black soil area of Northeast China is threatened by excessive exploitation of soil resources, leading inevitably to soil degradation. In the long run, the current production capacity of the soil may not sustain the long-term needs of a growing population under the current agricultural management level. Thus, control of soil erosion and prevention of organic matter loss have been proposed as critical strategies for sustained agriculture in this area (Luo et al., 2017; Lenka et al., 2017). In Northeast China, manure and corn straw have been used to improve soil fertility and crop yields (Hui et al., 2017; Tong et al., 2017; Liang et al., 2016). Moreover, carbon sequestration and bacterial soil contents have been improved using corn straw and manure (Yang et al., 2017; Ding et al., 2016). However, in contrast to these substrates, biochar (BC) is highly recalcitrant and unavailable to soil microorganisms (Sizmur et al., 2016).

Biochar, being a carbonaceous compound, has been used as a soil additive to counter the degradation of arable land (Luo et al., 2017). Several studies have been carried out on the effects of $\mathrm{BC}$ supplementation on soil aggregate formation and the physical properties of a variety of soils (Obia et al., 2016; Pratiwi and Shinogi, 2016; Lim et al., 2016; Guo, 2016). Indeed, Burrell et al. (2016) have reported that BC from straw improved the stability of soil aggregates in Planosol and Cambisol soils, and also improved the water availability to plants in Planosol soil by $38 \%$. A soil study in the Huang-Huai-Hai Plain, China revealed that treatment with BC significantly decreased the bulk density, but increased its total porosity (Du et al., 2016). Moreover, studies have been carried out on the effect of BC supplementation level on the physical and hydraulic properties of soil. In these studies, Igalavithana et al. (2017) applied corn residue $\mathrm{BC}$ at levels of $2.5,5.0,7.5$ and $10 \%\left(\mathrm{w}^{\cdot} \mathrm{w}^{-1}\right)$ in sandy loamy soil, and after equilibration for 30 days, there were highly significant exponential reductions in Ksat as a result of incorporation of $\mathrm{BC} 500$ at levels of up to $7.5 \%$, with Ksat approaching an asymptote at $10 \%$ BC500. In another study, it was shown that incubation of soil for 36 days with $\mathrm{BC}$ at levels of 1, 2, 5 and 10\% (by wt.) reduced the water losses through evaporation and stabilized the activities of some extracellular enzymes (Elzobair et al., 2016). In field experiments, Ippolito et al. (2016) reported that graded applications of BC (1, 2, and $10 \%$ by wt.) improved the water content of calcareous soil. Supplementation of podzolic soil with BC at levels of 10, 20 and $30 \mathrm{t} \mathrm{ha}^{-1}$ ) for 3 years produced significant and positive effects on the yield of winter rye (Kraska et al., 2016) However, most recent studies focused on low-fertility soils or under-leached, acidic saline soils. Thus, not much is known about the effect of levels of application of BC on crop yield and physical conditions of soil in degraded soils containing higher organic matter. The objective of the present study was to investigate the influence of different levels of maize straw-derived BC on continuous soybean production and soil properties such as physical environment and soil nitrifying bacteria. It was hypothesized that higher BC levels should exert positive and negative effects on soybean yield, as well as 
the physical properties of black soil. Three levels of BC supplementation $(15.75,31.5$ and $47.25 \mathrm{t} \mathrm{ha}^{-1}$ ), each mixed with a chemical fertilizer (NPK) separately in a selected field of black soil (Mollisols), were used. Crop yield and physical and hydraulic properties of soil such as compaction, aggregation stability, bulk density, hydraulic parameters and soil surface area were analyzed. The nitrifying bacteria in the BCsupplementaed soils were also evaluated.

\section{Materials and methods}

\section{Site, soil and biochar}

A long-term BC field experiment was initiated in Minzhu town, Daowai district in Haerbin city, China (E12651'05', N45'50'3”, Fig. 1). Climatological data, soil properties of surface layer and biochar properties can be seen in Tables 1, 2, and 3 respectively. Biochar applied in this study was derived from maize straw and manufactured by Liaoning Biochar Engineering Technology Center.

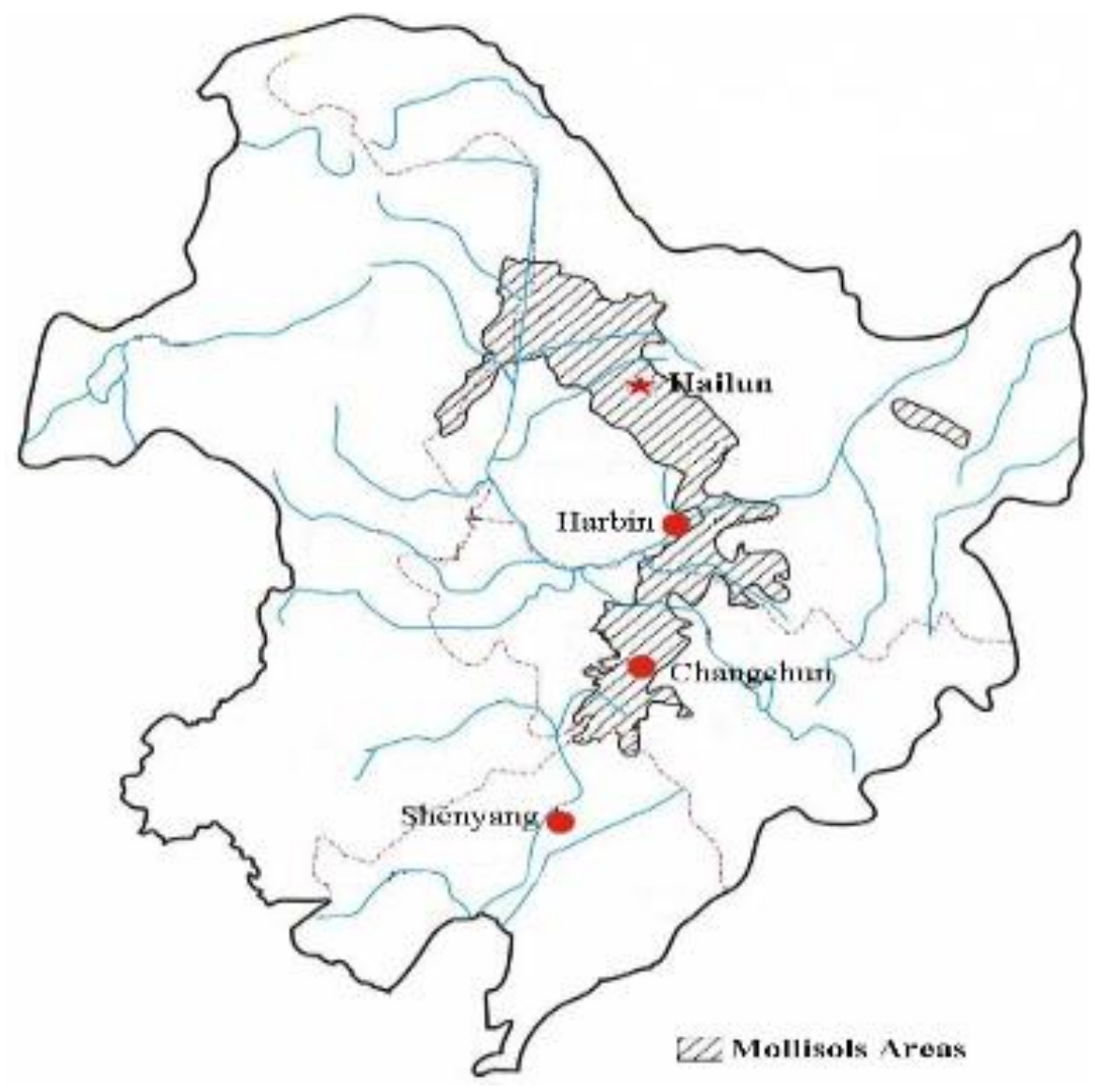

Figure 1. Map of study area

Table 1. Climatological data of experiment station

\begin{tabular}{c|c|c|c|c}
\hline $\begin{array}{c}\text { Average annual } \\
\text { rainfall }(\mathbf{m m})\end{array}$ & $\begin{array}{c}\text { Mean annual wind } \\
\text { speed }\left(\mathbf{m}_{\mathbf{s}} \mathbf{s}^{-\mathbf{1}}\right)\end{array}$ & $\begin{array}{c}\text { Maximum wind } \\
\text { speed }\left(\mathbf{m} \cdot \mathbf{s}^{-\mathbf{1}}\right)\end{array}$ & Sea level $(\mathbf{m})$ & $\begin{array}{c}\text { Ground water } \\
\text { table depth }(\mathbf{m})\end{array}$ \\
\hline 514 & 4.1 & 18.9 & 138 & 80 \\
\hline
\end{tabular}


Table 2. Basic chemical and physical properties in soil top layer in experiment plots

\begin{tabular}{|c|c|c|c|c|c|c|c|c|c|c|}
\hline Depth & Mecha & & a) & Texture & $\begin{array}{c}\text { Available } \\
\text { N }\end{array}$ & $\begin{array}{c}\text { Available } \\
\text { P }\end{array}$ & $\begin{array}{c}\text { Available } \\
\text { K }\end{array}$ & SOM* & pH & BD** \\
\hline cm & Sand & Silt & Clay & & mg.kg-1 & mg.kg-1 & mg.kg-1 & g.kg-1 & & g.cm $^{-3}$ \\
\hline $0-30$ & 21.8 & 56.3 & 21.9 & Silty clay loam & 163.3 & 20.61 & 187.92 & 29.87 & 6.74 & 1.31 \\
\hline
\end{tabular}

*SOM: soil organic matter; **BD: bulk density

Table 3. Biochar components

\begin{tabular}{|c|c|c|c|c|c|c|c|c|c|c|c|}
\hline \multicolumn{12}{|c|}{ Particle components \% } \\
\hline $\begin{array}{l}\text { SOC* } \\
\text { g.kg-1 }^{-1}\end{array}$ & $\begin{array}{c}O \\
\text { g.kg-1 }\end{array}$ & $\begin{array}{c}\mathbf{N} \\
\text { g.kg } \text {. }^{-1}\end{array}$ & $\begin{array}{c}P \\
\text { g.kg-1 }\end{array}$ & $\begin{array}{c}\text { K } \\
\text { g.kg }\end{array}$ & $\underset{\text { g.kg-1 }}{\mathbf{S i}}$ & $\begin{array}{c}\text { Mg } \\
\text { g.kg }\end{array}$ & $\underset{\text { g.kg }}{\mathrm{Ca}}$ & $\mathbf{p H}$ & $\begin{array}{l}<0.1 \\
\mathrm{~mm}\end{array}$ & $\begin{array}{c}0.1-2 \\
\mathrm{~mm}\end{array}$ & $\begin{array}{r}>2 \\
\mathrm{~mm}\end{array}$ \\
\hline 598 & 166 & 7.85 & 1.327 & 17.0 & 60 & 2 & 3 & 8.69 & 15.0 & 60.2 & 24.8 \\
\hline
\end{tabular}

*SOC: soil organic carbon

\section{Treatments}

A field experiment with soybean was carried out in 2013 and 2014. The treatments consisted of 3 levels of BC supplementation viz: NPK only, NPK $+\mathrm{BC}$ at level of 15.75 t.ha $^{-1}$ (BC1), NPK + BC at level of 31.50 t.ha ${ }^{-1}$ (BC2), and NPK + BC at level of 47.25 t.ha $^{-1}$ (BC3). Each treatment was replicated thrice. In order to guarantee soil and plant samling, every experiment plot was set up by covering an area of $39 \mathrm{~m}^{2}$ (6 ridges $\times 0.65 \mathrm{~m}$ width $\times 10 \mathrm{~m}$ ridge length). The sowing density of soybean was 300,000 plants per hectare. Soybean received sub-surface fertilizer application of $47 \mathrm{~kg}$ $\mathrm{N} \mathrm{ha}^{-1}, 78 \mathrm{~kg} \mathrm{P}_{2} \mathrm{O}_{5} \mathrm{ha}^{-1}$ and $68 \mathrm{~kg} \mathrm{~K}_{2} \mathrm{O} \mathrm{ha}^{-1}$, with which insecticide were applied of 0.13 to $0.2 \mathrm{~kg}$ chlorpyrifos granules $\mathrm{ha}^{-1}$ for controlling grubs. Spring soybean cultivar Heinong 58 was planted in May 2013 and harvested in October 2013, while the one planted on May 10, 2014 was harvested on October 5 in 2014. Prior to planting, the chemical fertilizer (NPK) for soybean was applied. In the 2013 period, the BC was spread over the furrow by the ridges. It was thoroughly mixed with soil using a ploughing machine (a tractor with a rototiller, Fig. 2), and then plowed to a depth of over $20 \mathrm{~cm}$ and then mainary ranked for a leveling. Herbicide applied over the ridges just after soybean sowing (Table 4).

Table 4. Basic physical and chemical properties of soil after harvest in 2014

\begin{tabular}{|c|c|c|c|c|c|c|c|c|c|c|}
\hline Treatment & $\begin{array}{c}N \\
(\%)\end{array}$ & $\begin{array}{c}\mathbf{H} \\
(\%)\end{array}$ & $\begin{array}{c}0 \\
(\%)\end{array}$ & $\begin{array}{l}\mathrm{C} \\
(\%)\end{array}$ & $\begin{array}{c}\text { BD* } \\
\text { g.cm } \\
\end{array}$ & $\begin{array}{c}\text { CEC** } \\
\text { cmol.kg }^{-1}\end{array}$ & $\begin{array}{c}\mathbf{S S A}^{* * * *} \\
\mathbf{m}^{2} \cdot \mathrm{g}^{-1}\end{array}$ & $\mathrm{C} / \mathrm{N}$ & $\mathrm{O} / \mathrm{C}$ & $\mathrm{H} / \mathrm{C}$ \\
\hline NPK & $\begin{array}{c}0.094 \pm \\
0.01 \mathrm{~d}\end{array}$ & $\begin{array}{c}0.666 \pm \\
0.01 \mathrm{a}\end{array}$ & $\begin{array}{c}2.290 \pm \\
0.09 b\end{array}$ & $\begin{array}{c}0.915 \pm \\
0.01 \mathrm{c}\end{array}$ & $\begin{array}{l}1.40 \pm \\
0.05 \mathrm{a}\end{array}$ & $\begin{array}{c}22.77 \pm \\
0.23 c\end{array}$ & $\begin{array}{c}29.35 \pm \\
0.43 \mathrm{~d}\end{array}$ & 9.76 & 2.50 & 0.73 \\
\hline $\mathrm{BC} 1 * * * *$ & $\begin{array}{c}0.179 \pm \\
0.02 \mathrm{c}\end{array}$ & $\begin{array}{c}0.624 \pm \\
0.03 \mathrm{a}\end{array}$ & $\begin{array}{c}2.344 \pm \\
0.13 \mathrm{a}\end{array}$ & $\begin{array}{c}1.800 \pm \\
0.02 \mathrm{a}\end{array}$ & $\begin{array}{l}1.28 \pm \\
0.03 b\end{array}$ & $\begin{array}{c}23.08 \pm \\
0.41 \mathrm{~b}\end{array}$ & $\begin{array}{c}32.74 \pm \\
0.61 \mathrm{a}\end{array}$ & 10.05 & 1.30 & 0.35 \\
\hline $\mathrm{BC} 2$ & $\begin{array}{c}0.186 \pm \\
0.01 \mathrm{~b}\end{array}$ & $\begin{array}{c}0.660 \pm \\
0.02 \mathrm{a}\end{array}$ & $\begin{array}{c}2.211 \pm \\
0.21 b\end{array}$ & $\begin{array}{c}1.150 \pm \\
0.03 b\end{array}$ & $\begin{array}{l}1.18 \pm \\
0.02 \mathrm{~d}\end{array}$ & $\begin{array}{c}24.72 \pm \\
0.53 \mathrm{a}\end{array}$ & $\begin{array}{c}31.62 \pm \\
0.21 b\end{array}$ & 6.17 & 1.92 & 0.57 \\
\hline BC3 & $\begin{array}{c}0.203 \pm \\
0.02 \mathrm{a}\end{array}$ & $\begin{array}{c}0.647 \pm \\
0.01 \mathrm{a}\end{array}$ & $\begin{array}{c}1.944 \pm \\
0.11 \mathrm{c}\end{array}$ & $\begin{array}{c}0.885 \pm \\
0.02 \mathrm{~d}\end{array}$ & $\begin{array}{l}1.22 \pm \\
0.02 \mathrm{c}\end{array}$ & $\begin{array}{c}24.10 \pm \\
0.20 \mathrm{a}\end{array}$ & $\begin{array}{c}30.19 \pm \\
0.20 c\end{array}$ & 4.37 & 2.20 & 0.73 \\
\hline
\end{tabular}

BD*: bulk density; CEC**: cation exchange capacity; SSA***: specific surface area; BC****: biochar 

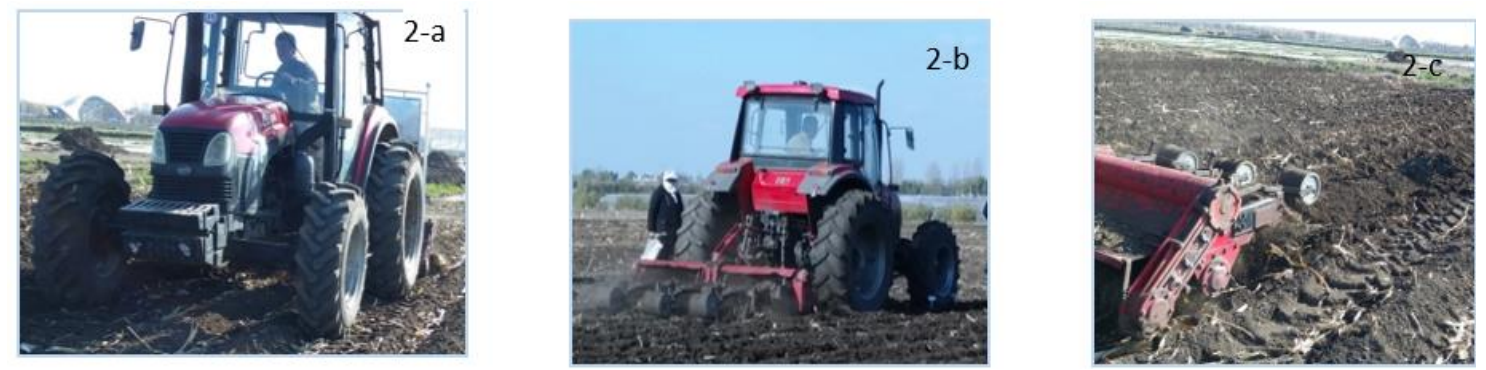

Figure 2. Ploughing machine working in the biochar-additive field plots

\section{Measurements}

\section{Particle size distribution of $B C$}

The particle size distribution of BC was determined by dry-sieving the samples using a sieve shaker (Endecott Test Sieve Shaker, Watson Victor Ltd.). Seven different fractions were obtained using $2.00,1.00,0.50,0.25$ and $0.106 \mathrm{~mm}$ sieves. Three consecutive shakings were conducted, and it was observed that the weights of different fractions remained unchanged. The first shaking was continued for $3 \mathrm{~min}$, and the other two shakings were done for only 2 min. Measurements of $\mathrm{N}_{2}$ gas adsorption for the determination of BET (Brunauer-Emmett-Teller) surface area of BC were carried out using a Micromeritics ASAP 2020 volumetric adsorption system.

\section{Soil compaction}

In the field, the soil compaction values were measured with in 2014 after the harvest of soybean with a soil compaction meter (SC-900, Fig. 3). The data for the top layer (0$20 \mathrm{~cm}$ ) were automatically recorded once every $2.5 \mathrm{~cm}$ as the soil compaction meter descended from the surface.

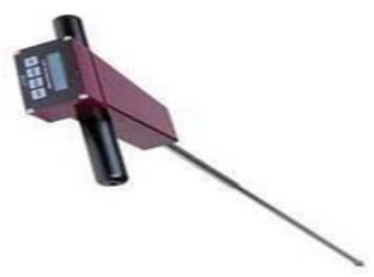

Figure 3. Soil compaction meter (SC-900)

\section{Soil aggregates and their stability parameters}

The size distribution of wet-sieving aggregates was determined with a rototap machine containing a nest of eight 100 -mm diameter sieves with screen openings of 10 , $7,5,2,1,0.5$ and $0.25 \mathrm{~mm}$. The weight of soil retained on each sieve was measured after dry-sieving $0.5 \mathrm{~kg}$ of soil for $2 \mathrm{~min}$. Moreover, $50 \mathrm{~g}$ of soil aggregates retained on $100 \mathrm{~mm}$ sieve was used for the analysis of wet-sieving which was carried out mechanically using Yoder's apparatus.

The nest of sieves used had mesh sizes of 2, 1, 0.5, 0.25 and $0.106 \mathrm{~mm}$. Wet sieving was continued for $20 \mathrm{~min}$ with 40 oscillations per min. The aggregates retained on each sieve were transferred to a set of pre-weighed beakers, oven-dried at $105^{\circ} \mathrm{C}$ for $24 \mathrm{~h}$, 
and weighed. The mean weight diameter (MWD) and geometric mean diameter (GMD) were calculated as indices of aggregation as shown in Equations 1 and 2:

$$
\begin{gathered}
M W D=\frac{\sum_{i=1}^{n}\left(\overline{d_{i}} W_{i}\right)}{\sum_{i=1}^{n} W_{i}} \\
G W D=\operatorname{EXP}\left[\frac{\sum_{i=1}^{n} W_{i} \ln \left(\overline{d_{i}}\right)}{\sum_{i=1}^{n} W_{i}}\right]
\end{gathered}
$$

where $\overline{\mathrm{d}}_{\mathrm{i}}$ is the mean diameter of the class $(\mathrm{mm})$, and $\mathrm{W}_{\mathrm{i}}$ is the proportion of aggregate retained on the sieves. The fractal dimension was determined in line with method of Yang et al. (1993), as shown in Equation 3:

$$
\frac{\mathrm{M}\left(\mathrm{r}<\overline{\left.x_{i}\right)}\right.}{M_{T}}=\left(\frac{\overline{x_{i}}}{x_{\max }}\right)^{3-D}
$$

where $\mathrm{M}\left(\mathrm{r}<\overline{\mathrm{X}}_{\mathrm{i}}\right)$ is the cumulative mass of objects or fragments of the $\mathrm{i}^{\text {th }}$ size, $\mathrm{r}<\overline{\mathrm{X}}_{\mathrm{i}}$; $\mathrm{M}_{\mathrm{T}}$ is the total mass of particles; $\bar{X}_{\mathrm{i}}$ is the mean particle diameter $(\mathrm{mm})$ of the $\mathrm{i}^{\text {th }}$ size class; and $\mathrm{X}_{\max }$ is the mean diameter of the largest particle.

\section{Hydraulic parameters}

The water retention curve $\theta(\mathrm{h})$ of soil was determined using the pressure plate method. Saturated hydraulic conductivity (Ks) was determined using a fixed-head permeameter instrument, and the parameters of $\theta(\mathrm{h})$ and unsaturated hydraulic conductivity K (h) were obtained using the van Genuchten-Mulem model (Eq. 4).

$$
\theta(\mathrm{h})=\theta_{r}+\frac{\theta_{s}-\theta_{r}}{\left.[1+\llbracket \alpha h]^{m}\right]^{m}}
$$

This equation was fitted on the moisture retention data of soil, and the parameters i.e. saturated water content $(\theta \mathrm{s})$, residual water content $(\theta \mathrm{r})$, inverse of suction at the inflexion point of the moisture curve $(a)$, and shape parameters $(m$ and $n$ ) were estimated through a non-linear least-squares optimization using RETC (RETention Curve) software.

\section{Pore size distribution}

The soil pore size distribution (PSD) was determined using mercury intrusion porosimetry (MIP) (Autopore IV 9500, Micromeritics Inc. USA). In the MIP method, the mercury pressure was increased stepwise, and the intruded volume of mercury was monitored for each pressure in the range of 0.0036-310 MPa. The MIP test indicates the volume of cumulative mercury intruded as a function of equivalent pore radius (EPR). The results obtained were plotted in two graphical forms: cumulative pore volume versus logarithmic EPR, and differential PSD versus logarithmic differentiation ( $\mathrm{dV} / \mathrm{d} \log \mathrm{r}$ ). The values of pore radii on the cumulative curve and differential curve were $0.003 \mu \mathrm{m}$ and $360 \mu \mathrm{m}$, respectively. This wide range allowed for the detection of diverse soil pore classes along the PSD curve. The pores were classified according to their equivalent pore diameter (EPD) into five classes of sizes: macropores (>75 $\mu \mathrm{m})$, 
mesopores $(30-75 \mu \mathrm{m})$, micropores $(5-30 \mu \mathrm{m})$, ultramicropores $(0.1-5 \mu \mathrm{m})$, and crytopores $(0.1-0.007 \mu \mathrm{m})$ according to the method of Camerson and Buchan (2006).

Soil ammonia bacteria [ammonia-oxidizing archaea (AOA) and ammonia-oxidizing bacteria $(A O B)]$

Total DNA was extracted from frozen soil samples (0.5 $\mathrm{g}$ wet weight) using a FastDNA ${ }^{\circledR}$ SPIN Kit For Soil (MP Biomedicals, LLC) in line with the manufacturer's instructions. The concentration and quality of the extracts were determined using UV spectrophotometer (Implen, München, Germany), and the extracts were kept at $-20{ }^{\circ} \mathrm{C}$ prior to further molecular analysis. Real-time PCR assays (total reaction volume $=20 \mu \mathrm{L}$ ) were carried out using SYBR ${ }^{\circledR}$ Premix Ex TaqTM Perfect Real Time (Takara, Dalian, China), and multicolor real-time PCR detection system (Bio-Rad Laboratories Inc., Hercules, CA, USA). The primer sets (AOA: Arch-amoAF/ArchamoAR; AOB: amoA-1F/amoA-2R) and thermal profiles used to amplify each target gene with real-time PCR are listed in Table 1. The abundance (copy number) of bacterial $\mathrm{AOA}$ and $\mathrm{AOB}$ genes were calculated using a regression equation to convert the cycle threshold $(\mathrm{Ct})$ values to the known number of copies in the standard curves.

\section{Statistical analysis}

All data were analyzed using Microsoft Excel (2003). The significance of differences among different treatments and sampling dates were tested with ANOVA using SPSS software package (SPSS Inc., 2003). Differences between values were considered statistically significant at $\mathrm{p}<0.05$. The coefficient of determination $\left(\mathrm{R}^{2}\right)$ of non-linear regression was used to determine the best fit of the water retention model of soil.

\section{Results}

\section{Site, soil and $B C$}

The effect of BC application on soybean yields (2013 and 2014) is shown in Figure 4. Soybean yields were significantly influenced by BC over two years, when compared with the control (NPK). In the first year, BC1, BC2 and BC3 increased soybean yields by $18.5,12.5$ and $9.7 \%$, respectively, when compared with NPK. Similarly, in the next year, increases in the soybean yield ranged from $15.4 \%$ (for BC1) to $4.6 \%$ (for BC3). The predominant yield for each year was produced by $\mathrm{BC} 1$.

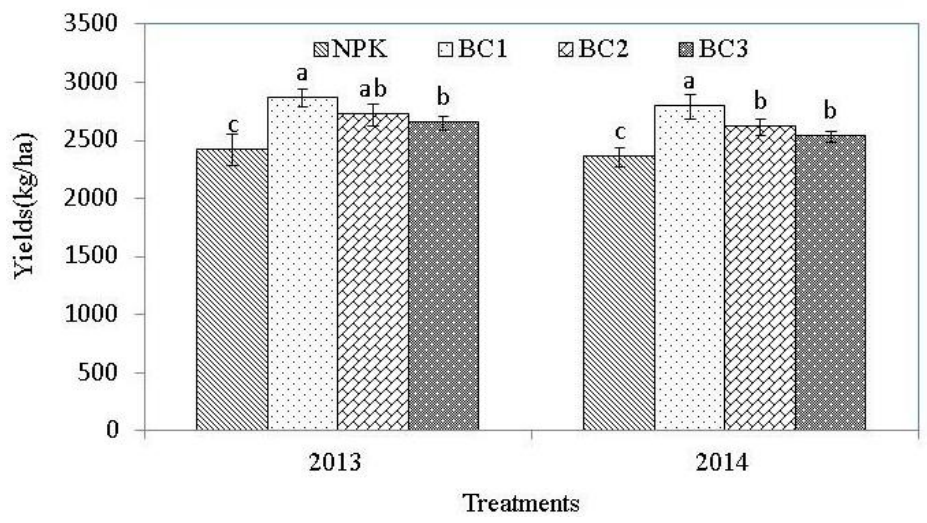

Figure 4. Effect of BC application on soybean yields from 2013 to 2014 


\section{Effect of field application of BC on the distribution of soil compaction in the top layer $(0-20 \mathrm{~cm})$}

Soil compaction reflects the conditions of pores in the soil and the strength of the junction force in the soil particles. After two years of field application of BC, there was an ' $S$ ' trend in the distribution of soil compaction values from the top of the soil $(0-$ $20 \mathrm{~cm}$ layer) for all treatments, and the compactability increased with increase in soil depth (Fig. 5A).

Compared with NPK treatment, $\mathrm{BC} 1, \mathrm{BC} 2$ and $\mathrm{BC} 3$ decreased average values of soil compactability distribution within $0-20 \mathrm{~cm}$ of soil by $47.4,38.4$ and $17.9 \%$, respectively. The order of average soil compaction values was $\mathrm{NPK}>\mathrm{BC} 3>\mathrm{BC} 2>\mathrm{BC} 1$. Except for NPK treatment, the strength of soil compaction was positively related to the supplementation level of $\mathrm{BC}$ i.e. $\mathrm{BC} 3>\mathrm{BC} 2>\mathrm{BC} 1$.
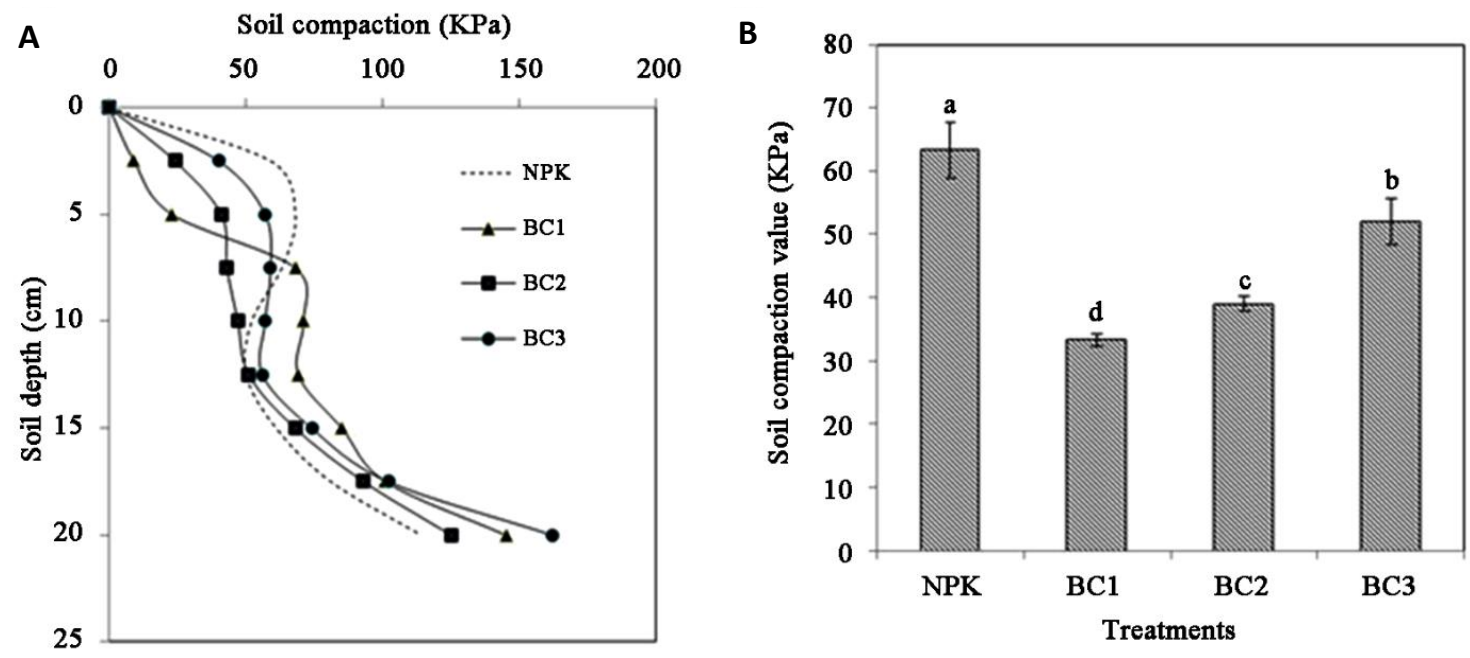

Figure 5. Effect of $B C$ on the distribution of soil compaction in the top soil layer $(0-20 \mathrm{~cm},(A)$; average soil compaction values at $0-20 \mathrm{~cm}(B)$

\section{Effect of field application levels of $\mathrm{BC}$ on the water-stable aggregates}

The details are presented in Table 5.

Table 5. Effect of level of supplementation of BC on the composition and stability indices of water-stable aggregates for two years

\begin{tabular}{|c|c|c|c|c|c|c|c|}
\hline \multirow{2}{*}{ Treatments } & \multicolumn{4}{|c|}{ Aggregate size composition (\%) } & \multirow{2}{*}{$\begin{array}{c}>0.25 \mathrm{~mm} \\
\text { Aggregates (\%) }\end{array}$} & \multirow{2}{*}{$\begin{array}{c}\text { MWD* } \\
(\mathbf{m m})\end{array}$} & \multirow{2}{*}{$\begin{array}{c}\text { GWD** } \\
(\mathbf{m m})\end{array}$} \\
\hline & $>2 \mathrm{~mm}$ & $2-0.25 \mathrm{~mm}$ & $0.25-0.106 \mathrm{~mm}$ & $<0.106 \mathrm{~mm}$ & & & \\
\hline NPK & \begin{tabular}{|c|}
$4.54 \pm$ \\
$0.21 \mathrm{c}$ \\
\end{tabular} & $\begin{array}{c}57.94 \pm \\
1.17 \mathrm{c} \\
\end{array}$ & \begin{tabular}{|c|}
$21.92 \pm$ \\
$1.35 \mathrm{~b}$
\end{tabular} & \begin{tabular}{|c|}
$15.60 \pm$ \\
$0.61 \mathrm{~b}$ \\
\end{tabular} & $\begin{array}{c}62.48 \pm \\
2.61 \mathrm{c}\end{array}$ & $\begin{array}{c}0.26 \pm \\
0.05 \mathrm{c} \\
\end{array}$ & $\begin{array}{c}0.27 \pm \\
0.01 \mathrm{a}\end{array}$ \\
\hline $\mathrm{BC} 1$ & $\begin{array}{l}7.60 \pm \\
0.41 \mathrm{a} \\
\end{array}$ & $\begin{array}{c}62.68 \pm \\
1.05 \mathrm{a} \\
\end{array}$ & $\begin{array}{c}19.22 \pm \\
1.89 \mathrm{c} \\
\end{array}$ & $\begin{array}{c}10.50 \pm \\
0.25 \mathrm{~d} \\
\end{array}$ & $\begin{array}{c}70.28 \pm \\
1.43 \mathrm{a} \\
\end{array}$ & $\begin{array}{c}0.33 \pm \\
0.02 \mathrm{a} \\
\end{array}$ & $\begin{array}{c}0.27 \pm \\
0.01 \mathrm{a} \\
\end{array}$ \\
\hline $\mathrm{BC} 2$ & $\begin{array}{l}6.40 \pm \\
0.11 \mathrm{~b} \\
\end{array}$ & $\begin{array}{c}60.76 \pm \\
2.06 \mathrm{~b}\end{array}$ & $\begin{array}{c}19.72 \pm \\
0.94 \mathrm{c}\end{array}$ & $\begin{array}{c}13.12 \pm \\
1.54 \mathrm{c}\end{array}$ & $\begin{array}{c}67.16 \pm \\
1.51 \mathrm{~b}\end{array}$ & $\begin{array}{l}0.30 \pm \\
0.01 \mathrm{~b}\end{array}$ & $\begin{array}{c}0.28 \pm \\
0.02 \mathrm{a}\end{array}$ \\
\hline $\mathrm{BC} 3$ & $\begin{array}{c}6.19 \pm \\
0.18 \mathrm{~d}\end{array}$ & $\begin{array}{c}49.01 \pm \\
1.03 \mathrm{~d}\end{array}$ & $\begin{array}{c}26.02 \pm \\
0.61 \mathrm{a}\end{array}$ & $\begin{array}{c}18.78 \pm \\
0.92 \mathrm{a}\end{array}$ & $\begin{array}{c}55.20 \pm \\
0.85 \mathrm{~d}\end{array}$ & $\begin{array}{c}0.27 \pm \\
0.04 \mathrm{c}\end{array}$ & $\begin{array}{l}0.28 \pm \\
0.01 \mathrm{a}\end{array}$ \\
\hline
\end{tabular}

$* \mathrm{MWD}=$ mean weight diameter; $* * \mathrm{GWD}=$ geometric mean diameter 


\section{Aggregate and its stability}

The results from wet-sieving (Table 5) showed that the addition of BC significantly affected the amounts of macroaggregates $(>0.25 \mathrm{~mm})$, which were increased by 12.5 , 7.5 and $-11.7 \%$ for $\mathrm{BC} 1, \mathrm{BC} 2$ and $\mathrm{BC} 3$, respectively, when compared to control (NPK). The changes in the aggregate sizes of $2-0.25 \mathrm{~mm}$ showed a positive relationship with MWD values with a correlation coefficient of $0.64(\mathrm{P}<0.05)$. The mean weight diameter (MWD), geometric mean diameter (GMD) can be used for amended-soil aggregates in the evaluation of the aggregation stability of soil. Higher values of these indices indicate the predominance of the more stable aggregates over the smaller, less stable fractions (Nath and Rattan, 2017; Rabot et al., 2018). From Table 5, after two years of the field application of BC in 2014, the MWDs of the of soil aggregate of the three treatments (BC1, BC2 and $\mathrm{BC} 3$ ) were enhanced by 26.6, 15.4 and $3.8 \%$, respectively over the control. No significant differences in GMD were found among the four treatments.

\section{Effect of BC on the hydraulic characteristics of soil}

Hydraulic parameters were significantly influenced by the level of $\mathrm{BC}$ incorporation, except in a few items in this study such as $\theta$ s (for $\mathrm{BC} 1, \mathrm{BC} 2$ and $\mathrm{BC} 3$ ) and total porosity (for $\mathrm{BC} 2$ and $\mathrm{BC} 3$ ) compared with the control (Table 6). Compared to NPK, the incorporation of maize BC at levels of $15.75,31.5$ and 47.25 t.ha $^{-1}$ increased field capacity to $0.379,0.381$ and $0.326 \mathrm{~cm} . \mathrm{cm}^{-1}$, respectively, from initial value of $0.291 \mathrm{~cm}$. $\mathrm{cm}^{-1}$. As shown in Table 6, wilting coefficient $\left(\theta_{r}\right)$ values were significantly reduced, while saturated water content $\left(\theta_{s}\right)$ values were not significantly increased at all levels of $\mathrm{BC}$ treatments $(\mathrm{p}<0.05)$. Smaller particle fraction in BC increased water holding space in black soil more significantly than larger particles (Tables 2 and 5). The results showed clearly that incorporation of BC at the level of $15.75 \mathrm{t}^{-h^{-1}}$ increased the soil $k_{s}$, $\theta_{s}$ and available water content by $50.14,17.94$ and $55.92 \%$, respectively, when compared to NPK control $(\mathrm{p}<0.05)$. The available water content refers to the difference between field capacity and wilting point; it is the quantity of soil water available for the usage of plants. The highest available water content was $0.332 \mathrm{~cm} . \mathrm{cm}^{-1}$ for the soil containing BC at the level of 15.75 t.ha ${ }^{-1}$, while BC at levels of 31.5 and 47.25 t.ha ${ }^{-1}$ decreased available water content to 0.316 and $0.266 \mathrm{~cm} \mathrm{~cm}^{-1}$, respectively. The regression equation for the available water capacity of soil as a function of level of incorporation of BC is shown in Equation 5:

Available water content $=-0.0002\left(\mathrm{t} \mathrm{ha}^{-1} \text { biochar }\right)^{2}+0.0126\left(\mathrm{t} \mathrm{ha}{ }^{-1}\right.$ biochar $)+0.2684$ (Eq.5)

It is clear from the quadratic equation that the addition of $\mathrm{BC}$ at the level of $15.75 \mathrm{t}^{-\mathrm{ha}^{-1}}$ increased available water content in the soil, but decreased it at levels of 30.5 and 47.25 t.ha $^{-1}\left(\mathrm{R}^{2}=0.9355\right)$. Field capacity was enhanced by $\mathrm{BC}$ incorporation, reaching the highest value of $0.382 \mathrm{~cm}^{-\mathrm{cm}^{-1}}$ ), but wilting point was significantly lower with $\mathrm{BC} 3$ than $\mathrm{BC} 2$. Thus, the difference (available water content) determined by the two coefficients for BC level of 15.75 t.ha $^{-1}$ was lower (0.329) than that for BC level of 31.5 t.ha ${ }^{-1}(0.328)$.

Figure 6 shows the regression models developed from the results on Table 6, which indicates the positive effect of $\mathrm{BC}$ on bulk density and available water content. The lower bulk density of the biochar-supplemented soil resulted directly from the 
contribution of pores of $\mathrm{BC}$, since the bulk density of $\mathrm{BC}$-excluded treatment was significantly lower than that of the unamended NPK control. This may be due to changes in total porosity. The results of hydraulic conductivity revealed an initial

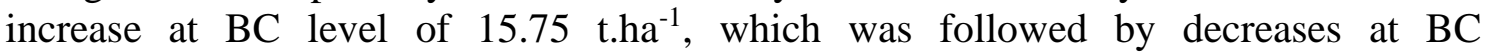
supplementation levels of 31.5 and $45.25 \mathrm{t}^{-\mathrm{ha}^{-1}}$. This may be due to the hydrophobic nature of organic matter in $\mathrm{BC}$.

Table 6. Effect of BC on hydraulic parameters of soil samples

\begin{tabular}{|c|c|c|c|c|c|c|c|c|}
\hline $\begin{array}{l}\text { Treatment } \\
(0-30 \mathrm{~cm})\end{array}$ & $\Theta r^{*}$ & $\Theta \mathbf{s}^{* *}$ & $a^{* * *}$ & $\mathbf{n}^{* * * *}$ & $\begin{array}{c}\mathbf{k}_{\mathrm{s}} * * * * \\
\left(\mathbf{m m} \cdot \min ^{-1}\right)\end{array}$ & $\begin{array}{c}\text { Field } \\
\text { capacity } \\
\left(\mathrm{cm}^{\left.-c^{-1}\right)}\right.\end{array}$ & $\begin{array}{c}\text { Available } \\
\text { water content } \\
\left(\mathbf{c m} . \mathrm{cm}^{-1}\right)\end{array}$ & $\begin{array}{c}\text { Total } \\
\text { porosity } \\
\%\end{array}$ \\
\hline NPK & $\begin{array}{c}0.080 \pm \\
0.005 \mathrm{a} \\
\end{array}$ & $\begin{array}{c}0.340 \pm \\
0.03 \mathrm{a} \\
\end{array}$ & $\begin{array}{c}0.078 \pm \\
0.01 \mathrm{a} \\
\end{array}$ & $\begin{array}{l}1.96 \pm \\
0.17 \mathrm{~b}\end{array}$ & $\begin{array}{c}10.71 \pm \\
0.56 \mathrm{~d} \\
\end{array}$ & $\begin{array}{c}0.291 \pm \\
0.02 \mathrm{~d} \\
\end{array}$ & $\begin{array}{c}0.211 \pm \\
0.02 \mathrm{~d} \\
\end{array}$ & $\begin{array}{c}47.16 \pm \\
2.61 \mathrm{~d} \\
\end{array}$ \\
\hline $\mathrm{BC} 1$ & $\begin{array}{c}0.050 \pm \\
0.003 \mathrm{~b}\end{array}$ & $\begin{array}{c}0.401 \pm \\
0.01 \mathrm{~b}\end{array}$ & $\begin{array}{c}0.017 \pm \\
0.01 \mathrm{~d}\end{array}$ & $\begin{array}{l}1.71 \pm \\
0.09 \mathrm{c}\end{array}$ & $\begin{array}{c}16.08 \pm \\
0.42 \mathrm{a}\end{array}$ & $\begin{array}{c}0.379 \pm \\
0.03 \mathrm{~b}\end{array}$ & $\begin{array}{c}0.329 \pm \\
0.03 c\end{array}$ & $\begin{array}{c}55.47 \pm \\
1.51 \mathrm{a}\end{array}$ \\
\hline $\mathrm{BC} 2$ & $\begin{array}{c}0.056 \pm \\
0.002 \mathrm{c}\end{array}$ & $\begin{array}{c}0.397 \pm \\
0.02 \mathrm{~b}\end{array}$ & $\begin{array}{c}0.035 \pm \\
0.01 \mathrm{~b}\end{array}$ & $\begin{array}{c}2.28 \pm \\
0.15 \mathrm{a}\end{array}$ & $\begin{array}{c}15.48 \pm \\
0.23 \mathrm{~b}\end{array}$ & $\begin{array}{c}0.381 \pm \\
0.01 \mathrm{a}\end{array}$ & $\begin{array}{c}0.325 \pm \\
0.02 \mathrm{a}\end{array}$ & $\begin{array}{c}53.96 \pm \\
0.49 \mathrm{~b}\end{array}$ \\
\hline $\mathrm{BC} 3$ & $\begin{array}{c}0.060 \pm \\
0.005 \mathrm{~d}\end{array}$ & $\begin{array}{c}0.389 \pm \\
0.02 \mathrm{~b}\end{array}$ & $\begin{array}{c}0.023 \pm \\
0.02 \mathrm{c}\end{array}$ & $\begin{array}{c}1.05 \pm \\
0.3 \mathrm{~d}\end{array}$ & $\begin{array}{c}11.90 \pm \\
1.05 \mathrm{c}\end{array}$ & $\begin{array}{c}0.326 \pm \\
0.03 c\end{array}$ & $\begin{array}{c}0.266 \pm \\
0.02 \mathrm{~b}\end{array}$ & $\begin{array}{c}51.70 \pm \\
0.84 \mathrm{~b}\end{array}$ \\
\hline
\end{tabular}

$* \theta_{r}=$ soil residual water content/wilting coefficient $\left(\mathrm{cm}^{3} \cdot \mathrm{cm}^{-3}\right)$; $* * \theta_{s}=$ soil saturated water content $\left(\mathrm{cm}^{3} \cdot \mathrm{cm}^{-3}\right) ; * * * \alpha$ and $n=$ parameters related to the shape of the soil water characteristics curve; $* * * * k_{s}=$ hydraulic conductivity
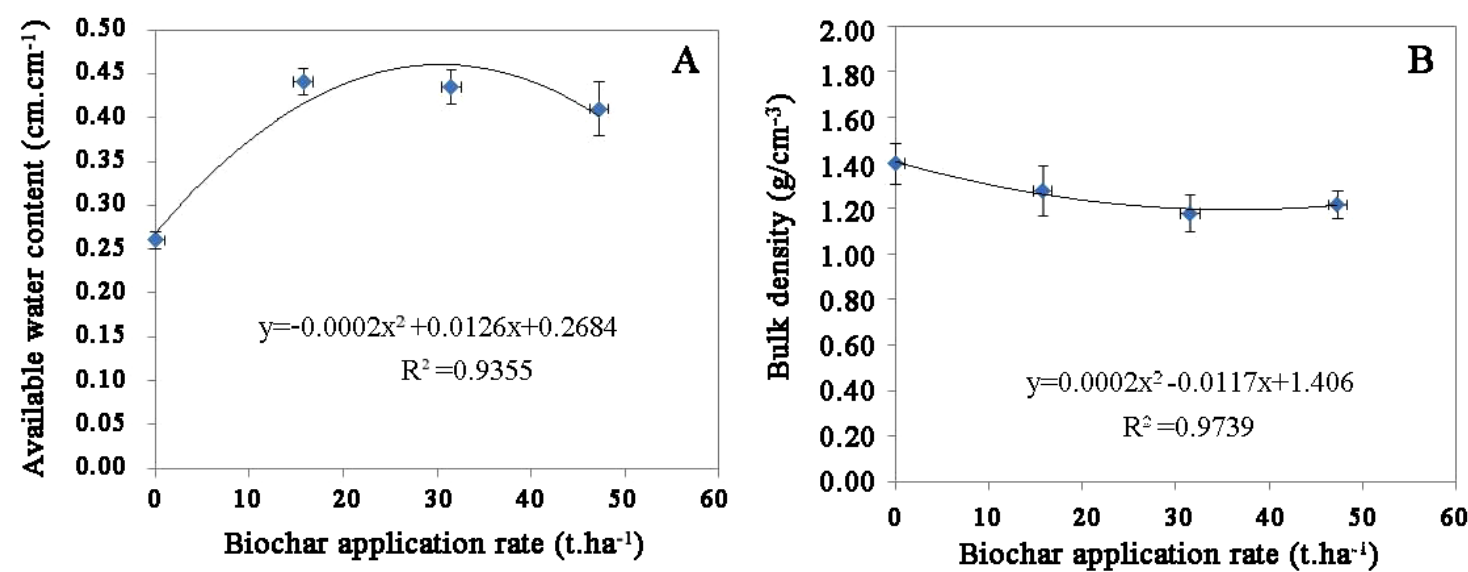

Figure 6. Regression models for the physical properties and the level of incorporation of BC. A: model for available water content and level of BC supplementation; B: model for bulk density and level of incorporation of $B C$

\section{Effect of BC on the pore distribution of soil}

The results of pore analysis porosity and pore size distribution of BC-amended soils are shown in Table 7. Total pore volume and porosity of soils were higher $(\mathrm{p}<0.05)$ in BC-treated soils than in NPK control soil. The degree to which the total porosity values increased with the $\mathrm{BC}$ incorporation level varied among the treated soils. The relative increases in total porosity due to $\mathrm{BC} 1, \mathrm{BC} 2$ and $\mathrm{BC} 3$ were 17.6, 14.4, and 9.6\%, respectively, relative to NPK control. The $\mathrm{BC}$ treatment caused significant changes in 
the pore in the ranges of $>75,30-75,5-30$, and $0.1-5 \mu \mathrm{m}$, which indicates that it indeed altered the macro-, meso-, and micropores. However, BC did not significantly affect the crytopores $(<0.1 \mu \mathrm{m})$. In SB-amended soil, approximately $32 \%$ of the total porosity was in $>75 \mu \mathrm{m}$ pores, followed by $0.1-5 \mu \mathrm{m}$ class (approximately $25 \%$ ), 5-30 $\mu \mathrm{m}$ class (approximately 14\%), and 0.01-0.1 $\mu \mathrm{m}$ class (approximately 8\%). The changes in pore size distribution brought about by $\mathrm{BC}$ treatments could possibly reflect the particle size distribution of $\mathrm{BC}$. Compared with $\mathrm{BC} 1, \mathrm{BC}$ at the higher level of 31.5 t.ha $^{-1}$ increased the total volume, but decreased the macropores and mesopores by 53.54 and $16.50 \%$, respectively, indicating that $\mathrm{BC} 2$ produced more unavailable pores leading to less available water in the soil. Compared with $\mathrm{BC} 2$, the $78.76 \%$ increase in $5-30 \mu \mathrm{m}$ micropores, and $74.42 \%$ decrease in $30-75 \mu \mathrm{m}$ mesopores are in agreement with the hypothesis that direct changes in capillary pores are caused by the occupation of finer $\mathrm{BC}$ particles, leading to decreased available water content at $\mathrm{BC}$ levels of 31.5 and 47.5 t.ha $^{-1}$.

Table 7. Total porosity and pore-size distribution of BC-amended soils

\begin{tabular}{c|c|c|c|c|c|c|c|c}
\hline \multirow{2}{*}{ Treatment } & \multirow{2}{*}{$\begin{array}{c}\text { Total } \\
\text { volume } \\
\left(\mathbf{c m}^{\mathbf{3}} \mathbf{g}^{-1}\right)\end{array}$} & $\begin{array}{c}\text { Total } \\
\text { porosity } \\
(\boldsymbol{\%})\end{array}$ & $\mathbf{7 5} \boldsymbol{\mu m}$ & $\mathbf{3 0 - 7 5} \boldsymbol{\mu m}$ & $\mathbf{5 - 3 0} \boldsymbol{\mu m}$ & $\mathbf{0 . 1 - 5} \boldsymbol{\mu m}$ & $\mathbf{0 . 1 - 0 . 0 1} \boldsymbol{\mu m}$ & $<\mathbf{0 . 0 1} \boldsymbol{\mu m}$ \\
& & & & & & \\
\hline \multirow{2}{*}{$\mathrm{NPK}$} & $0.2559 \pm$ & $47.16 \pm$ & $0.0975 \pm$ & $0.0234 \pm$ & $0.0365 \pm$ & $0.0600 \pm$ & $0.0261 \pm$ & $0.0124 \pm$ \\
& $0.01 \mathrm{~d}$ & $1.52 \mathrm{~d}$ & $0.03 \mathrm{~b}$ & $0.01 \mathrm{c}$ & $0.0028 \mathrm{c}$ & $0.0041 \mathrm{c}$ & $0.0017 \mathrm{c}$ & $0.0005 \mathrm{~b}$ \\
\hline \multirow{2}{*}{$\mathrm{BC} 1$} & $0.4115 \pm$ & $55.47 \pm$ & $0.1892 \pm$ & $0.0988 \pm$ & $0.0224 \pm$ & $0.0598 \pm$ & $0.0288 \pm$ & $0.0125 \pm$ \\
& $0.02 \mathrm{~b}$ & $0.97 \mathrm{a}$ & $0.05 \mathrm{a}$ & $0.03 \mathrm{a}$ & $0.0019 \mathrm{~d}$ & $0.0057 \mathrm{c}$ & $0.0011 \mathrm{~b}$ & $0.0002 \mathrm{~b}$ \\
\hline \multirow{2}{*}{$\mathrm{BC} 2$} & $0.4201 \pm$ & $53.96 \pm$ & $0.0879 \pm$ & $0.0825 \pm$ & $0.053 \pm$ & $0.1389 \pm$ & $0.0455 \pm$ & $0.0123 \pm$ \\
& $0.01 \mathrm{a}$ & $1.12 \mathrm{~b}$ & $0.04 \mathrm{~d}$ & $0.01 \mathrm{~b}$ & $0.0049 \mathrm{~b}$ & $0.0093 \mathrm{a}$ & $0.0035 \mathrm{a}$ & $0.0004 \mathrm{~b}$ \\
\hline \multirow{2}{*}{$\mathrm{BC} 3$} & $0.3197 \pm$ & $51.70 \pm$ & $0.0910 \pm$ & $0.0211 \pm$ & $0.0771 \pm$ & $0.0902 \pm$ & $0.0271 \pm$ & $0.0132 \pm$ \\
& $0.01 \mathrm{c}$ & $2.51 \mathrm{c}$ & $0.01 \mathrm{c}$ & $0.02 \mathrm{~d}$ & $0.0065 \mathrm{a}$ & $0.065 \mathrm{~b}$ & $0.0012 \mathrm{bc}$ & $0.0003 \mathrm{a}$ \\
\hline
\end{tabular}

\section{Effect of BC incorporation level on the soil nitrifying oxidizers}

Changes in soil nitrifying bacteria [soil ammonia-oxidizing archaea (AOA) and soil ammonia-oxidizing bacteria $(\mathrm{AOB})]$ of $\mathrm{BC}$-treated soils are presented in Table 8. Values of $\mathrm{AOA}$ and $\mathrm{AOB}$ ranged from 0.91 to $1.16 \times 10^{8} \mathrm{cfu}^{-1} \mathrm{~g}^{-1}$, and from 0.65 to $0.76 \times 10^{7} \mathrm{cfu} . \mathrm{g}^{-1}$, respectively.

Table 8. The abundance of soil nitrifying bacteria of biochar-amended soils during harvest in 2014

\begin{tabular}{c|c|c|c}
\hline \multirow{2}{*}{ Treatment } & AOA $\left.\mathbf{( 1 0}^{\mathbf{8}}\right)$ & AOB $\left.\mathbf{( 1 0}^{\mathbf{7}}\right)$ & \multirow{2}{*}{ pH } \\
\cline { 2 - 3 } & Cfu.g $^{-1}$ & Cfu.g $^{-1}$ & $6.80 \pm 0.23 \mathrm{a}$ \\
NPK & $1.09 \pm 0.03 \mathrm{~b}$ & $0.65 \pm 0.03 \mathrm{~b}$ & $7.13 \pm 0.51 \mathrm{~b}$ \\
BC1 & $1.16 \pm 0.02 \mathrm{a}$ & $0.81 \pm 0.02 \mathrm{a}$ & $7.29 \pm 0.34 \mathrm{c}$ \\
BC2 & $0.97 \pm 0.04 \mathrm{c}$ & $0.73 \pm 0.02 \mathrm{~b}$ & $7.65 \pm 0.13 \mathrm{~b}$ \\
\hline BC3 & $0.91 \pm 0.05 \mathrm{~cd}$ & $0.76 \pm 0.04 \mathrm{ab}$ & \\
\hline
\end{tabular}

Similar to $\mathrm{pH}$, AOA abundance was significantly enhanced by the addition of BC, when compared to NPK, but AOB was not significantly increased. The ratio of AOB to 
AOA increases with increasing $\mathrm{pH}$ gradient in the rhizosphere (Yu et al., 2019). Biochar at the level in $\mathrm{BC} 1$ enhanced $\mathrm{AOA}$ and $\mathrm{AOB}$ copies, but decreased them in $\mathrm{BC} 2$ and BC3.

\section{Discussion}

The application of $\mathrm{BC}$ enhances crop yields as well as a range of physical properties of soil (Laird et al., 2017; Agegnehu et al., 2016; Burrell et al., 2016; Du et al., 2016). In addition, BC influences soil nitrifying bacteria (Pan et al., 2017; Radwan et al., 2018; Azerang et al., 2018). The application of BC significantly increased the yield of soybean due to soil structure and improvement in moisture content as a result of changes in soil nitrifying bacteria. This can be attributed to the enhanced specific surface area and higher porosity as seen in the present study, which have been shown to enhance microbial activity and increase SOM (Chen et al., 2017; Ren et al., 2018; Sripreechasak et al., 2018; Sangdee et al., 2017). When BC is applied under the influence of tillage and cultivation operations, the distribution of soil compaction in the top layer of soil could be due to a dilution effect for the lighter fraction at the top layer $(0-20 \mathrm{~cm})$ (Soane, 1990). It has been reported that microaggregate formation and aggregate stability are significantly improved by the addition of BC (Kaiser et al., 2017; Hartley et al., 2016). The macroaggregates of black soil were significantly increased by incorporation of maize straw-derived $\mathrm{BC}$ at the levels of 15.75 and $31.5 \mathrm{t}^{-h a^{-1}}$, and the stability of BC1 (15.75 t.ha ${ }^{-1}$ ) was enhanced in the additive treatments. On the other hand, BC at levels of 31.5 and 47.25 t.ha $^{-1}$ produced negative effects on aggregate formation, leading to decreases in percentage of macroaggregates and lower MWD values, relative to $\mathrm{BC} 1$. This may be partially due to the fine particles with excessive biochar occupying the exist capillary under the external forces of mechanical cultivation and rainfall (Busscher et al., 2010) and then the restrict of microbial activity and nitrogen mineralization (Dempster et al., 2012) leading to less soil cement existed in unit soil mass. Another reason could be the effect of excessive $\mathrm{BC}$ which effectively decreased the risk of surface sealing in the BC-amended soils, relative to BC1 (Sun and $\mathrm{Lu}, 2014)$. Moreover, the $\mathrm{C}: \mathrm{N}$ ratio of $\mathrm{BC} 1$ was the highest (10.05, Table 4), whereas the $\mathrm{O}: \mathrm{C}$ and $\mathrm{H}: \mathrm{C}$ ratios were the lowest (1.32 and 0.35, respectively, Table 4) among the four treatments (Table 4). Generally, a critical C:N ratio of $<25$ is important because it indicates the probability of net mineralization of nitrogen (Chapin et al., 2002). The stability of BC-amended soil with a dominant level of BC could also be reflected in O:C and $\mathrm{H}: \mathrm{C}$ ratios, the correlation coefficient of which was positive 0.97 . The lower values of the two ratios resulted in a more stable BC-amended soil (Spokas, 2010; Budai et al., 2013), which could be a major factor that influences the formation of soil aggregates.

The effect of application of $\mathrm{BC}$ on water retention capacity is linked to the improvement of soil aggregation or structure (Ibrahim et al., 2017). The available water content in the soil was increased by BC addition at the level of 15.75 t.ha-1, but was decreased at $\mathrm{BC}$ levels of 31.5 and $47.25 \mathrm{t}^{-h^{-1}}$ mainly due to the changes in the capillary pores of the $\mathrm{BC}$-amended soil. The negative effect of these changes could be due to the partial replacement of the clay particles by the finer particles in the BC, followed by a decrease in wilting point. Studies by Nadeem et al. (2017) showed that $\mathrm{BC}$ enhanced field capacity, which is consistent with the outcomes of this study. In a series of well constrained laboratory experiments, Liu et al. (2017a) showed that BC particle sizes affected soil water content by changing the pore spaces between particles 
(interpores), and by adding pores that are part of the biochar (intrapores). Moreover, it has been reported that $\mathrm{BC}$ treatment either decreases (clogs) or increases pore spaces in the mixture, based on the quantity of fine BC fraction, which in turn could decrease or increase the hydraulic conductivity of the mixture (Trifunovic et al., 2018).

The addition of excess amount of BC (15.75 t.ha $\left.^{-1}\right)$ probably led to filling up of some of the capillary pores existing in the BC-amended soil by the additional dust $(<0.1 \mathrm{~mm})$ that accompanied BC. Thus, the water holding capacity of the soil was reduced at higher $\mathrm{BC}$ levels. It has been reported that fine particles of excessive $\mathrm{BC}$ fill the soil pores, thereby reducing the permeability while increasing the water retention of $\mathrm{BC}$ amended soil (Uzoma et al., 2011; Busscher et al., 2010). This provides the physical environment in response to changes in soil nitrifying bacteria. Similar to the available water content of soil, bulk density is a parameter which is useful for measuring the relative mass of a solid relative to the bulk volume that the solid occupies, including void spaces. For the non-amended soil, the bulk density was $1.40 \mathrm{~cm} . \mathrm{cm}^{-1}$, and was decreased to $1.28,1.18$, and $1.22 \mathrm{~g} . \mathrm{cm}^{-3}$ by $\mathrm{BC} 1, \mathrm{BC} 2$ and $\mathrm{BC} 3$, respectively. Bulk density also showed a quadratic regression relationship with increasing level of $\mathrm{BC}$ $\left(\mathrm{R}^{2}=0.97\right)$. Recent studies on the negative effect of high $\mathrm{BC}$ application on soil-plant system revealed that addition of $\mathrm{BC}$ at levels of 10,20 and $30 \mathrm{t} \mathrm{ha}^{-1}$ produced positive influence on grain yield of winter rye, with $20 \mathrm{t} \mathrm{ha}^{-1}$ resulting in the highest grain yields (Kraska et al., 2016). Pot experiments revealed that $S$. salsa yield increased from 11.7 to $115 \%$ with WS application in the range of 5-10 $\mathrm{g} \mathrm{kg}^{-1}$, when compared with control (Sun et al., 2016). However, as BC level increased to $20 \mathrm{~g} \mathrm{~kg}^{-1}$, the yield decreased to $102 \%$. Usowicz et al. (2016) have reported that incorporation of BC under the fallow led to reduction of soil bulk density and particle density from $1.18-1.20 \mathrm{mg} \mathrm{m}^{-3}$ and 2.48-2.55 mg m${ }^{-3}$ from 0 t.ha $^{-1}$ and $10 \mathrm{t} \mathrm{ha}^{-1}$ to $1.00 \mathrm{Mg} \mathrm{m}^{-3}$ and $2.20 \mathrm{Mg} \mathrm{m}^{-3}$ under $30 \mathrm{t} \mathrm{ha}^{-1}$, respectively. In a field experiment conducted by Liu et al. (2017b), it was found that BC supplementation at levels of 10 and $20 \mathrm{~g} \mathrm{~kg}^{-1}$ soil increased peanut nitrogen fixation by 15.52 and $14.11 \%$, respectively, in an intercropping system where maize (Zea mays L.) was intercropped with either soybean (Glycine max L.) or peanut (Arachis hypogaea L.).

The results obtained in this study reveal that $\mathrm{BC}$ exerts both positive and negative effects on the physical environment of black soil, and provide a real growth condition for crop yield, depending on the level of application. Higher concentrations of AOA and AOB improve the conversion of other forms of nitrogen to available nitrogen fertilizer so as to enhance the fertility of soil and promote plant growth (Luo and Lin, 2013). The bacterial indices $\mathrm{AOA}$ and $\mathrm{AOB}$ are the real driving forces, with $\mathrm{AOA}$ being more sensitive to changes in soil rhizosphere environment, especially $\mathrm{pH}$. Indeed, AOA may be regarded as a factor for direct assessment of the benefits of $\mathrm{BC}$, which is in agreement with the results observed in a hydroagric Stagnic Anthrosol and an entic Halpudept (Lin et al., 2017). In this study, increases in $\mathrm{pH}$ occurred along with increases in AOB: AOA ratio, leading to increased nitrogen mineralization by stimulating mircrobial activity (Teutscherova et al., 2017). On the other hand, AOA was reduced at higher BC levels mainly due to adverse physical condition of soil, especially decreased availability of water and capillary pores, which negatively affected rhizosphere soil nutrient supply required for crop growth. 


\section{Conclusion}

Maize-derived BC incorporation increased the yields of soybean, and improved the physical properties of black soil such as aggregation stability, water holding capacity and pore size distribution. It is evident that as the level of application of BC increased to 37.5 and $47.25 \mathrm{t} \mathrm{ha}^{-1}$, soil aggregation became less stable, possibly due to the negative effect on microbial habitat, leading to decreased stability of soil aggregates and lower levels of binding agents per unit of soil volume. Similarly, available water holding capacity started to decreases at $\mathrm{BC}$ level of $37.5 \mathrm{t} \mathrm{ha}^{-1}$, due mainly to the filling of the capillary pore space of $\mathrm{BC}$-soil mixture with finer ashes in excess BC. Moreover, AOA and $\mathrm{AOB}$ were enhanced by the lowest $\mathrm{BC}$ level (BC1), but inhibited at higher levels (BC2 and $\mathrm{BC} 3$ ), which resulted in direct reduction of crop yield by affecting the nitrogen supply capacity of rhizosphere soil. It is necessary that these results are verified in long-time field observations. Therefore, it can be concluded from these results that the maize straw-derived $\mathrm{BC}$ can be applied to black soils as a strategy for optimization of sustainable agricultural production.

Acknowledgements. This research was funded by national Natural Science Foundation of China (41977095; 31901479; 41771284), the Special Fund for National Key R\&D Program of China (2018YFD0201000; 2017YFD0200803), Heilongjiang Natural Science Foundation (No. ZD2017008), and we thank the reviewers and issue editor of the journal for the valuable comments and suggestions that led to significant improvements of this manuscript.

\section{REFERENCES}

[1] Agegnehu, G., Bass, A. M., Nelson, P. N., Bird, M. I. (2016): Benefits of biochar, compost and biochar-compost for soil quality, maize yield and greenhouse gas emissions in a tropical agricultural soil. - Science of the Total Environment 543: 295-306.

[2] Azerang, P., Sardari, S., Kobarfard, F., Owlia, P., Farahani, Y. F. (2018): Isolation of membrane-active fraction of Streptomyces spp. from soil. - Tropical Journal of Pharmaceutical Research 17(5): 849-855.

[3] Budai, A., Zimmerman, A. R., Cowie, A. L., Webber, J. B. W., Singh, B. P., Glaser, B., Joseph, S. (2013): Biochar carbon stability test method: an assessment of methods to determine biochar carbon stability. - Carbon Methodology, IBI Document, 20 September.

[4] Burrell, L. D., Zehetner, F., Rampazzo, N., Wimmer, B., Soja, G. (2016): Long-term effects of biochar on soil physical properties. - Geoderma 282: 96-102.

[5] Busscher, W. J., Novak, J. M., Evans, D. E., Watts, D. W., Niandou, M. A. S., Ahmedna, M. (2010): Influence of pecan biochar on physical properties of a Norfolk loamy sand. Soil Science 175(1): 10-14.

[6] Cameron, K. C., Buchan, G. D. (2006): Porosity and Pore-Size Distribution. - In: Lal, R. (ed.) Encyclopedia of Soil Science, CRC, Boca Raton, pp. 1350-1353.

[7] Chapin III, F. S., Matson, P. A., Mooney, H. A. (2002): Terrestrial Nutrient Cycling. - In: Chapin, F. S. I., Matson, P. A., Mooney, H. A. (eds.) Principles of Terrestrial Ecosystem Ecology. Springer-Verlag, New York.

[8] Chen, J., Li, S., Liang, C., Xu, Q., Li, Y., Qin, H., Fuhrmann, J. J. (2017): Response of microbial community structure and function to short-term biochar amendment in an intensively managed bamboo (Phyllostachys praecox) plantation soil: effect of particle size and addition rate. - Science of the Total Environment 574: 24-33.

[9] Dempster, D. N., Gleeson, D. B., Solaiman, Z. I., Jones, D. L., Murphy, D. V. (2012): Decreased soil microbial biomass and nitrogen mineralisation with Eucalyptus biochar addition to a coarse textured soil. - Plant and Soil 354(1-2): 311-324. 
[10] Ding, J., Jiang, X., Ma, M., Zhou, B., Guan, D., Zhao, B., Zhou, J., Cao, F., Li, L., Li, J. (2016): Effect of 35 years inorganic fertilizer and manure amendment on structure of bacterial and archaeal communities in black soil of northeast China. - Applied Soil Ecology 105: 187-195.

[11] Du, Z., Chen, X., Qi, X., Li, Z., Nan, J., Deng, J. (2016): The effects of biochar and hoggery biogas slurry on fluvo-aquic soil physical and hydraulic properties: a field study of four consecutive wheat-maize rotations. - Journal of Soils and Sediments 16(8): 20502058.

[12] Elzobair, K. A., Stromberger, M. E., Ippolito, J. A. (2016): Stabilizing effect of biochar on soil extracellular enzymes after a denaturing stress. - Chemosphere 142: 114-119.

[13] Golley, J., Wei, Z. (2015): Population dynamics and economic growth in China. - China Economic Review 35: 15-32.

[14] Gonzalo, J. A., Alfonseca, M., Munoz, F. F. (2016): World Population: Past, Present and Future. Chap. 4: World Population Growth. - World Scientific Publishing, Singapore.

[15] Guo, M. (2016): Application of biochar for soil physical improvement. - Agricultural and Environmental Applications of Biochar: Advances and Barriers, SSSA Special Publication 63: 101-122.

[16] Hartley, W., Riby, P., Waterson, J. (2016): Effects of three different biochars on aggregate stability, organic carbon mobility and micronutrient bioavailability. - Journal of Environmental Management 181: 770-778.

[17] Hui, L. I., Feng, W. T., He, X. H., Ping, Z. H. U., Gao, H. J., Nan, S. U. N., Xu, M. G. (2017): Chemical fertilizers could be completely replaced by manure to maintain high maize yield and soil organic carbon (SOC) when SOC reaches a threshold in the Northeast China Plain. - Journal of Integrative Agriculture 16(4): 937-946.

[18] Ibrahim, A., Usman, A. R. A., Al-Wabel, M. I., Nadeem, M., Ok, Y. S., Al-Omran, A. (2017): Effects of conocarpus biochar on hydraulic properties of calcareous sandy soil: influence of particle size and application depth. - Archives of Agronomy and Soil Science 63(2): 185-197.

[19] Igalavithana, A., Ok, Y., Niazi, N., Rizwan, M., Al-Wabel, M., Usman, A., Lee, S. (2017): Effect of corn residue biochar on the hydraulic properties of sandy loam soil. Sustainability 9(2): 266.

[20] Ippolito, J. A., Stromberger, M. E., Lentz, R. D., Dungan, R. S. (2016): Hardwood biochar and manure co-application to a calcareous soil. - Chemosphere 142: 84-91.

[21] Kaiser, M., Grunwald, D., Koch, H. J., Rauber, R., Ludwig, B. (2017): Influence of the individual or combined application of biochar and slurry on soil macro-aggregate formation under varying moisture conditions. - EGU General Assembly Conference Abstracts. Vol. 19, EGU2017-6581.

[22] Kraska, P., Oleszczuk, P., Andruszczak, S., Kwiecińska-Poppe, E., Różyło, K., Pałys, E., Gierasimiuk, P., Michałojć, Z. (2016): Effect of various biochar rates on winter rye yield and the concentration of available nutrients in the soil. - Plant, Soil and Environment 62(11): 483-489.

[23] Laird, D. A., Novak, J. M., Collins, H. P., Ippolito, J. A., Karlen, D. L., Lentz, R. D., Sistani, K. R., Spokas, K., Van Pelt, R. S. (2017): Multi-year and multi-location soil quality and crop biomass yield responses to hardwood fast pyrolysis biochar. - Geoderma 289: 46-53.

[24] Lenka, N. K., Satapathy, K. K., Lal, R., Singh, R. K., Singh, N. A. K., Agrawal, P. K., Choudhury, P., Rathore, A. (2017): Weed strip management for minimizing soil erosion and enhancing productivity in the sloping lands of north-eastern India. - Soil and Tillage Research 170: 104-113.

[25] Liang, W., Yuan, J. C., Zhang, H. X. (2016): Research progress on mechanism and related technology of corn straw returning in Northeast China. - Journal of Northeast Agricultural Sciences 41(2): 44-49. 
[26] Lim, T. J., Spokas, K. A., Feyereisen, G., Novak, J. M. (2016): Predicting the impact of biochar additions on soil hydraulic properties. - Chemosphere 142: 136-144.

[27] Lin, Y., Ding, W., Liu, D., He, T., Yoo, G., Yuan, J., Fan, J. (2017): Wheat straw-derived biochar amendment stimulated $\mathrm{N}_{2} \mathrm{O}$ emissions from rice paddy soils by regulating the amoA genes of ammonia-oxidizing bacteria. - Soil Biology and Biochemistry 113: 8998.

[28] Liu, L., Wang, Y., Yan, X., Li, J., Jiao, N., Hu, S. (2017a): Biochar amendments increase the yield advantage of legume-based intercropping systems over monoculture. Agriculture, Ecosystems \& Environment 237: 16-23.

[29] Liu, Z., Dugan, B., Masiello, C. A., Gonnermann, H. M. (2017b): Biochar particle size, shape, and porosity act together to influence soil water properties. - PloS One 12(6): 0179079.

[30] Luo, J., Lin, W. T. (2013): Research progress of ammonia-oxidizing archaea. - Journal of South China University of Technology 41(12): 107-114.

[31] Luo, X., Liu, G., Xia, Y., Chen, L., Jiang, Z., Zheng, H., Wang, Z. (2017): Use of biochar-compost to improve properties and productivity of the degraded coastal soil in the Yellow River Delta, China. - Journal of Soils and Sediments 17(3): 780-789.

[32] Nadeem, S. M., Imran, M., Naveed, M., Khan, M. Y., Ahmad, M., Zahir, Z. A., Crowley, D. E. (2017): Synergistic use of biochar, compost and plant growth-promoting rhizobacteria for enhancing cucumber growth under water deficit conditions. - Journal of the Science of Food and Agriculture 97(15): 5139-5145.

[33] Nath, A. J., Rattan, L. A. L. (2017): Effects of tillage practices and land use management on soil aggregates and soil organic carbon in the north Appalachian region, USA. Pedosphere 27(1): 172-176.

[34] Obia, A., Mulder, J., Martinsen, V., Cornelissen, G., Børresen, T. (2016): In situ effects of biochar on aggregation, water retention and porosity in light-textured tropical soils. Soil and Tillage Research 155: 35-44.

[35] Pan, F., Chapman, S. J., Li, Y., Yao, H. (2017): Straw amendment to paddy soil stimulates denitrification but biochar amendment promotes anaerobic ammonia oxidation. - Journal of Soils and Sediments 17(10): 2428-2437.

[36] Pratiwi, E. P. A., Shinogi, Y. (2016): Rice husk biochar application to paddy soil and its effects on soil physical properties, plant growth, and methane emission. - Paddy and Water Environment 14(4): 521-532.

[37] Rabot, E., Wiesmeier, M., Schlüter, S., Vogel, H. J. (2018): Soil structure as an indicator of soil functions: a review. - Geoderma 314: 122-137.

[38] Radwan, A. M., Reyad, N. F., Donia, A. E. R. M., Ganaie, M. A. (2018): Comparative studies on the effect of environmental pollution on secondary metabolite contents and genotoxicity of two plants in Asir area, Saudi Arabia. - Tropical Journal of Pharmaceutical Research 17(8): 1599-1605.

[39] Ren, X., Zeng, G., Tang, L., Wang, J., Wan, J., Liu, Y., Yu, J., Yi, H., Ye, S., Deng, R. (2018): Sorption, transport and biodegradation-an insight into bioavailability of persistent organic pollutants in soil. - Science of the Total Environment 610: 1154-1163.

[40] Sangdee, K., Buranrat, B., Seephonkai, P., Surapong, N., Sangdee, A. (2017): Investigation of antibacterial and anti-cancer activities of Streptomyces sp SRF1 culture filtrate. - Tropical Journal of Pharmaceutical Research 16(11): 2727-2734.

[41] Sizmur, T., Quilliam, R., Puga, A. P., Moreno-Jiménez, E., Beesley, L., Gomez-Eyles, J. L. (2016): Application of biochar for soil remediation. - Agricultural and Environmental Applications of Biochar: Advances and Barriers, SSSA Special Publication 63: 295-324.

[42] Soane, B. D. (1990): The role of organic matter in soil compactibility: a review of some practical aspects. - Soil and Tillage Research 16(1-2): 179-201.

[43] Spokas, K. A. (2010): Review of the stability of biochar in soils: predictability of O:C molar ratios. - Carbon Management 1(2): 289-303. 
[44] Sripreechasak, P., Phongsopitanun, W., Supong, K., Tanasupawat, S. (2018): Lipolytic and antimicrobial activities of Pseudomonas strains isolated from soils in Phetchaburi Province, Thailand. - Tropical Journal of Pharmaceutical Research 17(3): 499-505.

[45] Sun, F., Lu, S. (2014): Biochars improve aggregate stability, water retention, and porespace properties of clayey soil. - Journal of Plant Nutrition and Soil Science 177(1): 2633.

[46] Sun, J., He, F., Shao, H., Zhang, Z., Xu, G. (2016): Effects of biochar application on Suaeda salsa growth and saline soil properties. - Environmental Earth Sciences 75(8): 16.

[47] Teutscherova, N., Vazquez, E., Masaguer, A., Navas, M., Scow, K. M., Schmidt, R., Benito, M. (2017): Comparison of lime-and biochar-mediated $\mathrm{pH}$ changes in nitrification and ammonia oxidizers in degraded acid soil. - Biology and Fertility of Soils 53(7): 811821.

[48] Tong, Y., Liu, J., Li, X., Sun, J., Herzberger, A., Wei, D., Zhang, W., Dou, Z., Zhang, F. (2017): Cropping system conversion led to organic carbon change in China's Mollisols Regions. - Scientific Reports 7(1): 18064.

[49] Trifunovic, B., Gonzales, H. B., Ravi, S., Sharratt, B. S., Mohanty, S. K. (2018): Dynamic effects of biochar concentration and particle size on hydraulic properties of sand. - Land Degradation \& Development 29(4): 884-893.

[50] Usowicz, B., Lipiec, J., Lukowski, M., Marczewski, W., Usowicz, J. (2016): The effect of biochar application on thermal properties and albedo of loess soil under grassland and fallow. - Soil and Tillage Research 164: 45-51.

[51] Uzoma, K. C., Inoue, M., Andry, H., Zahoor, A., Nishihara, E. (2011): Influence of biochar application on sandy soil hydraulic properties and nutrient retention. - Journal of Food Agriculture and Environment 9: 1137-1143.

[52] Yang, P. L., Luo, Y. P., Shi, Y. C. (1993): Soil fractal characteristics measured by mass of particle-size distribution. - Chinese Science Bulletin 38(20): 1896-1899.

[53] Yang, X., Meng, J., Lan, Y., Chen, W., Yang, T., Yuan, J., Liu, S., Han, J. (2017): Effects of maize stover and its biochar on soil $\mathrm{CO} 2$ emissions and labile organic carbon fractions in Northeast China. - Agriculture, Ecosystems \& Environment 240: 24-31.

[54] Yin, G., Guo, G. (2015): Analysis on China's mid- and long-term food supply and demand trend. - Journal of South China Agricultural University 2: 76-83.

[55] Yu, M., Meng, J., Yu, L., Su, W., Afzal, M., Li, Y., Xu, J. (2019): Changes in nitrogen related functional genes along soil $\mathrm{pH}, \mathrm{C}$ and nutrient gradients in the charosphere.Science of the Total Environment 650: 626-632. 